JURNAL BASICEDU

Research \& Learning in Elementary Education

https://jbasic.org/index.php/basicedu

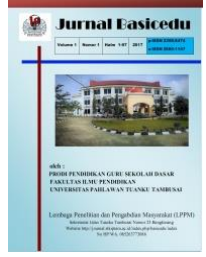

\title{
LITERASI MEMBACA UNTUK MENINGKATKAN KARAKTER POSITIF SISWA SEKOLAH DASAR
}

\author{
Nang Suarni ${ }^{1}$, Taufina ${ }^{2}$, Ahmad Zikri ${ }^{3}$ \\ Universitas Negeri Padang, Sumatera Barat, Indonesia ${ }^{1,2,3}$ \\ Email Nangsuarni@gmail.com ${ }^{1}$, taufina taufik@yahoo.co.id ${ }^{2}$, zikria79@yahoo.com ${ }^{3}$
}

\begin{abstract}
Abstrak
Penggunaan Cerita Rakyat telah banyak dikembangkan diseluruh dunia terutama di Indonesia. Tujuan penelitian ini adalah: (1) menentukan apakah literasi membaca dengan menggunakan cerita rakyat yang dilakukan membentuk karakter positif (2) dan durasi efkenya. Tiga puluh siswa kelas V SD yang berpatisipasi penelitian ini. Hasil untuk anak-anak yang mengikuti kegiatan membaca literasi membaca menggunakan cerita rakyat untuk membentuk karakter positif, tetapi dalam minggu pertama kurang tampaknya efek karakter positif siswa. Minggu ketiga siswa diajak kembali untuk berpatisipasi mengikuti literasi membaca dengan menggunakan cerita rakyat. Jumlah anak-anak yang menunjukan karakter positif meningkat setelah mengikuti kegiatan pada minggu ketiga. Hasilnya menunjukan bahwa (1) Kegiatan literasi membaca berdampak positif pada pembentuk karakter siswa, (2) durasi efek pembentukan karakter positif berlangsung bisa singkat.
\end{abstract}

Kata Kunci: Literasi ,Membaca,Sekolah Dasar.

\begin{abstract}
Abstrack
The use of Folklore has been widely developed throughout the world, especially in Indonesia. The objectives of this study are: (1) determine whether literacy reading using folklore is carried out to form positive characters (2) and the duration of effect. Thirty grade V elementary school students participated in this study. Results for children who take part in reading literacy reading activities use folklore to form positive characters, but in the first week the effects of students' positive characters seem less. The third week students are invited back to participate in reading literacy using folklore. The number of children who showed positive character increased after participating in activities in the third week. The results show that (1) reading literacy activities have a positive impact on student character building, (2) the duration of the effect of positive character formation can be short.
\end{abstract}

Keywords: Literacy, Reading, Elementary School

@ Jurnal Basicedu Prodi PGSD FIP UPTT 2019

$\triangle$ Corresponding author :

Address : Lubuk Buaya Kota Padang

Email : nangsuarni@gmail.com

ISSN 2580-3735 (Media Cetak)

Phone : 089531307164 
1015 Literasi membaca untuk meningkatkan karakter positif siswa sekolah dasar-Nang Suarni, Taufina, Ahmad Zikri

\section{PENDAHULUAN}

Kajian utama dalam literasi membaca tertuju pada empat hal, yaitu: (1) keterampilan membaca; (2) penerapan, pelatihan, dan penetapan bacaan; (3) proses membaca; dan (4) teks yang digunakan dalam membaca (PIRLS, 2015:12). Salah satu jenis membaca dalam literasi membaca adalah membaca pemahaman. Memandang literasi membaca dari segi keterampilan membaca pemahaman bermuara pada teknik membaca pemahaman yang digunakan. Teknik membaca pemahaman yang benar, yaitu: membaca dengan tidak bersuara, bibir tidak komat-kamit, tidak menggerakkan kepala mengikuti baris bacaan, dan tidak menunjuk baris bacaan. Memperhatikan teknik membaca lancar akan melahirkan kualitas membaca peserta didik yang lebih baik.

Penguasaan keterampilan peserta didik yang lebih baik, harus memperhatikan penerapan teknik membaca pemahaman, pelatihan terbimbing membaca pemahaman, dan penetapan bacaan yang digunakan dalam membaca pemahaman. Pelatihan terbimbing sebagai nuturan efek dari isi teks bacaan bermuara pada tindakan komunikasi dalam mengkaji maksud dari bacaan dan terciptanya perubahan sikap yang diharapkan berdasarkan isi teks bacaan. Pahamnya isi teks bacaan juga dipengaruhi oleh penerapan proses membaca yang sesungguhnya. Proses membaca yang sesungguhnya terdiri atas tiga tahap, yaitu: (1) prabaca, (2) saat baca, dan (3) pascabaca (Somadayo, 2011:35-38). Proses membaca juga memperhatikan penggunaan teks bacaan yang ditetapkan.

Teks bacaan yang disediakan dalam literasi membaca harus menggunakan bahasa yang dimengerti oleh peserta didik. Bahan bacaan yang digunakan juga memuat petunjuk yang jelas dan mudah untuk dipahami, sehingga peserta didik tidak mengalami kesulitan dalam membaca. Hal lain yang perlu diperhatikan yaitu penggunaan teks yang sesuai dengan perkembangan peserta didik, sehingga menimbulkan ketertarikan peserta didik dalam mengikuti maksud dari literasi membaca. Selain itu, perubahan sikap berdasarkan pemaknaan yang dilakukan dalam proses membaca teks bacaan membawa peserta didik menuju pengaplikasian sikap yang lebih baik sesuai dengan yang seharusnya. Perubahan sikap menuju yang lebih baik merupakan aplikasi pembentukan karakter positif.Pembentukan karakter dapat dilakukan dalam proses pembelajaran dengan adanya pendidikan karakter. Pendidikan karakter hendaknya dapat meningkatkan keterampilan peserta didik untuk menjaga keutuhanbangsa, membangun masyarakat yang berakhlak mulia, menjadi bangsa yang maju dibandingkan bangsa lain, meningkatkan kemakmuran bangsa, dan mampu menegakkan keadilan (Gede, 2012).

Keempat kajian utama dalam literasi membaca dapat dibelajarkan dengan adanya persiapan yang harus dilakukan. Salah satu persiapan dapat ditemukan pada bahan ajar yang digunakan. Peran serta bahan ajar merupakan hal pokok yang tidak bisa terlepas dari proses pembelajaran yang dilaksanakan. Oleh sebab itu, kesiapan bahan ajar merupakan faktor penentu berhasil-tidaknya proses pembelajaran literasi membaca yang diberikan di SD.Bahan ajar literasi membaca mengacu pada ketersediaan teks bacaan. Bahan ajar yang dikembangkan dengan 
1016 Literasi membaca untuk meningkatkan karakter positif siswa sekolah dasar-Nang Suarni, Taufina, Ahmad Zikri

menggunakan cerita rakyat yang tepat akan menumbuhkan usaha kreatif penemuan sendiri isi bacaan oleh peserta didik. Proses penemuan yang dilakukan akan memberikan pengalaman belajar yang berarti bagi peserta didik dalam implementasi literasi membaca. Pengalaman akan terlihat ketika peserta didik mampu memahami isi bacaan, menyerap informasi, dan mengaplikasikan ilmu yang diperoleh. Oleh sebab itu, kesiapan bahan ajar merupakan faktor penentu berhasil tidaknya implementasi literasi membaca di SD.

Berdasarkan analisis kebutuhan dengan guru kelas $\mathrm{V}$ di beberapa SD kota Padang melalui pengamatan dan wawancara penulis selama dua minggu, ditemukan beberapa kebutuhan dan permasalahan utama. Pertama, guru SD membutuhkan bahan ajar literasi membaca yang sesuai dengan perkembangan peserta didik. Namun, bahan ajar yang ada belum menggambarkan proses literasi membaca yang efektif. Proses yang sering ditinggalkan adalah prabaca. Artinya, pembelajaran membaca jarang diawali dengan adanya proses memprediksi isi bacaan. Ketidakmunculan proses memprediksi isi bacaan disebabkan oleh bahan ajar yang belum memuatnya (Triplett, 2002:123).

Kedua, bahan ajar membaca pemahaman yang dilaksanakan pada kelas $\mathrm{V}$ masih kurang memperhatikan teknik membaca pemahaman, sehingga ditemukan peserta didik yang kurang mengaplikasikan teknik membaca pemahman. Peserta didik berusaha memahami teks bacaan dengan berbisik. Saat membaca, peserta didik bahkan masih menunjuk teks bacaan. Artinya, teknik membaca pemahaman masih jarang diaplikasikan peserta didik yang menyebabkan tingkat keterampilan membaca pemahaman demi memahami isi teks bacaan peserta didik masih rendah. Hal ini seiring dengan hasil studi yang dilakukan oleh PISA (Programme for International Student Assessment) pada tahun 2006 bahwa keterampilan membaca pemahaman peserta didik Indonesia masih rendah (Mullis dkk, 2011:8).

Ketiga, bahan ajar yang digunakan jarang menggunakan cerita rakyat sebagai media pembelajaran yang berdaya guna untuk memperbaiki sikap siswa menuju karakter positif. Cerita rakyat yang ada dibiarkan hilang begitu saja, sehingga siswa kurang mengenali cerita rakyat yang ada dilingkungannya. Padahal cerita rakyat dapat menjadi salah satu bahan yang digunakan untuk mengajak siswa mengenali literasi membaca serta membentuk karakter positif sesuai dengan amanat yang terdapat di dalam cerita rakyat.

Keempat, kualitas pemahaman teks bacaan yang dimiliki peserta didik juga dipengaruhi oleh ketersediaan gambar. Namun, gambar yang digunakan masih kurang menarik. Gambar masih kurang mewakili isi teks bacaan dan belum berwarna. Oleh sebab itu, dapat dikatakan bahwa masih ditemukan bahan bacaan yang kurang menarik menyebabkan peserta didik kurang gemar membaca (Ngaka dan Masaaki, 2015:90).

Kelima, masih ditemukan karakter negatif sebagai bentuk kekeliruan peserta didik terhadap aplikasi tontonan media. Pembekalan karakter masih jarang diaplikasikan. Hal ini berdampak buruk pada dunia pendidikan dan memunculkan kekhawatiran guru terhadap sikap yang tidak sepatutnya. Kekhawatiran yang dirasakan juga disebabkan realita sikap peserta didik yang sudah tidak terkendali seperti yang diinformasikan dalam media masa. Salah satu kasus yang fenomenal 
1017 Literasi membaca untuk meningkatkan karakter positif siswa sekolah dasar-Nang Suarni, Taufina, Ahmad Zikri

terjadi di Bukittinggi pada tanggal 18September 2014. Beberapa peserta didik putra SD memukuli seorang peserta didik putri. Mereka menghujani temannya dengan pukulan dan tendangan di Kota Bukittinggi, Sumatera Barat .Selain ini juga terjadi kasus-kasus serupa yang tidak dipublikasikan.

Mengatasi masalah yang dikemukakan, guru hendaknya mengembangkan bahan ajar membaca secara efektif dan kreatif. Namun, agar lebih terarah dalam penggunaannya, bahan ajar yang dikembangkan hendaknya menggunakan cerita rakyat. Cerita rakyat dapat diartikan sebagai ekspresi budaya suatu masyarakat melalui bahasa tutur yang berhubungan langsung dengan berbagai aspek budaya dan susunan nilai sosial masyarakat tersebut. Dahulu, cerita rakyat diwariskan secara turun-temurun dari satu generasi ke generasi berikutnya secara lisan (Suripan Sadi Hutomo, 1991:4). Cerita rakyat sangat digemari oleh warga masyarakat karena dapat dijadikan sebagai suri tauladan. Oleh karena itu, cerita rakyat biasanya mengandung ajaran budi pekerti atau pendidikan moral bagi masyarakat sebagai pembentuk karakter positif.

Cerita rakyat yang dapat digunakan di lingkungan SD diharapkan siswa dapat lebih memperhatikan teks bacaan dan meningkatkan rasa ingin tahu serta memiliki daya tarik tersendiri bagi siswa terhadap teks bacaan. Sebagaimana menurut Anies Baswedan, hal yang perlu dilakukan yaitu mengajarkan anak membaca, lalu membiasakan anak membaca hingga menjadi karakter, setelah itu barulah menjadi budaya.Jadi, budaya membaca itu hadir karena ada kebiasaan membaca. Kebiasaan membaca ada jika ada rencana membaca secara rutin dan rutinitas dalam membaca.

\section{METODE}

Penelitian ini menggunakan penelitian kualitatif. Masing-masing Sekolah
Dasar di kota-kota Sumatera Barat diberikan surat undangan untuk merekrut peserta. Dalam undangan itu, kami meminta dua orang perwakilan siswa kelas $\mathrm{V}$ di masing-masing Sekolah Dasar untuk berpartisipasi dalam penelitian. Ruangan terdiri dari 30 siswa kelas lima sekolah dasar (18 anak laki-laki dan 12 perempuan) dengan usia rata-rata 11 tahun. Semua anak-anak di kelas mengikuti kegiatan literasi membaca dengan menggunakan cerita rakyat.

Dua minggu sebelum kegiatan, orang tua dari siswa yang berpartisipasi diberitahu bahwa para guru setuju dengan pelaksanaan program. Para guru di tiap sekolah dasar memberikan perincian kepada orang tua tentang kegiatan literasi membaca dengan menggunakan cerita rakyat yang diisi melalui surat. Para orang tua diyakinkan bahwa kerahasiaan informasi pribadi anak-anak mereka akan dilindungi. Semua orang tua setuju untuk mengizinkan anak-anak mereka untuk berpartisipasi dalam kegiatan tersebut dengan menandatangani surat persetujuan yang di berikan di setiap sekolah.

Tiga puluh buku cerita rakyat dengan sepuluh judul cerita berbeda di berikan kepada siswa untuk melihat ketertarikan siswa dengan cerita tersebut. Buku tersebut boleh dibawa kemana-kemana dengan syarat tidak boleh dibawa pulang kerumah. Para guru di kelas memeriksa ketertarikan siswa dengan buku cerita tersebut dengan perilaku berikut: (a) siswa selalu membawa buku kemanapun ia berada di dalam kelas, (b) saat membaca siswa tidak terpengaruh oleh gangguan temannya, (c) saat membaca siswa merasa menjadi tokoh tersebut, (d) saat membaca terlihat menikmati 
1018 Literasi membaca untuk meningkatkan karakter positif siswa sekolah dasar-Nang Suarni, Taufina, Ahmad Zikri

dengan gerakan berupa senyuman, gerak kaki, tangan di goyangkan, (e) saat selesai kegiatan siswa selalu ingin membawa pulang cerita tersebut. Kami memutuskan bahwa anak telah tertarik dengan buku cerita rakyatnya jika terlihat setidaknya dua dari lima perilaku yang diamati tadi. Setidaknya butuh satu minggu untuk memastikan siswa telah tertarik atau terikat dengan buku cerita rakyat yang telah dibaca.

Pada kegiatan anak memerankan peran menjadi tokoh, guru lainya melakukan pengukuran. Guru tersebut tidak mengetahui tujuan penelitian ini. Pengukuran dilakukan untuk melihat sejauh mana sifat positif yang di timbulkan anak selama proses memerankan tokoh cerita rakyat. Dengan menggunakan angket pengukuran bisa lebih tepat. Perilaku yang di nilai dalam angket yaitu : (1) bekerja sama, (2) tanggung jawab, dan (3) percaya diri. Setiap perilaku memiliki indikator yang diamati yaitu (1) bekerja sama indikatornya (terlibat aktif dalam kelompok, bersedia menerima peran yang disepakati, bersedia membantu kelompok jika mengalami kesulitan), (2) tanggung jawab (menjalankan peran yang telah diberikan, menerima resiko dari peran yang di dapat, menjalankan peran sesuai dengan urutan yang ditentukan), (3) percaya diri (membaca naskah secara lancar, memainkan peran dengan tubuh yang tegap, tidak takut dengan peran apapun yang di dapat). Setiap perilaku positif terlihat jika dua indikator telah terlihat.

\section{HASIL DAN PEMBAHASAN}

Di dalam kelas terdapat banyak buku cerita dengan sepuluh cerita rakyat yang berbeda-beda.
Panitia membebaskan para siswa untuk memilih cerita rakyat yang mereka sukai. Namun pada awal kegiatan sebagian siswa tidak memanfaatkan kesempatannya untuk membaca buku cerita lain dan sibuk dengan aktivitas mereka sendiri-sendiri. Perlu beberapa kali kegiatan agar siswa memunculkan perilaku tertarik siswa akan cerita rakyat tersebut. Kemudian pada saat kegiatan literasi membaca siswa menunjukan keseriusan dalam membaca buku cerita rakyat.

Hal itu karena pada kegiatan awal sebelumnya membuat siswa terbiasa untuk membaca cerita rakyat secara berulang-ulang. Selama dalam kegiatan siswa dibentuk dalam kelompok untuk memerankan salah satu cerita rakyat yang terdapat dalam buku. Selain itu siswa tampak kebingungan menetukan peran masingmasing tokoh karena ada beberapa tokoh yang mengharuskan siswa memerankan peran ganda dan berpengaruh pada aspek sikap tanggung jawab siswa dalam perannya.

Hasil penelitian terhadap karakter siswa pada hari pertama dilakukan kegiatan literasi terjadi peningkatan perilaku. Siswa diminta memerankan tokoh dari cerita yang telah ia baca. Observer mengamati perilaku siswa yang terlihat selama kegiatan literasi. Perilaku yang terlihat antara lain: Sebanyak 22 siswa terlihat bekerja sama dan 8 siswa tidak terlihat bekerja sama, sebanyak 20 siswa terlihat bertanggung jawab dan 10 siswa, 20 siswa terlihat percaya diri dan 10 siswa tidak percaya diri.

Tabel 1. Perilaku Pada Hari Pertama

\begin{tabular}{|c|c|c|}
\hline $\begin{array}{c}\text { Kerja sama } \\
\text { (Cooperate) }\end{array}$ & $\begin{array}{c}\text { Tanggung Jawab } \\
\text { (Responble) }\end{array}$ & $\begin{array}{c}\text { Percaya Diri } \\
\text { (Confidence) }\end{array}$ \\
\hline 22 & 20 & 20 \\
\hline
\end{tabular}

Hasil penelitian terhadap karakter siswa pada minggu pertama dilakukan kegiatan literasi. Observer mengamati perilaku siswa yang terlihat selama kegiatan literasi. Perilaku yang terlihat antara lain: Sebanyak 23 siswa terlihat bekerja 
1019 Literasi membaca untuk meningkatkan karakter positif siswa sekolah dasar-Nang Suarni, Taufina, Ahmad Zikri

sama dan 7 siswa tidak terlihat bekerja sama, sebanyak 22 siswa terlihat bertanggung jawab dan 8 siswa, 21 siswa terlihat percaya diri dan 9 siswa tidak percaya diri.

Tabel 2. Perilaku Pada Minggu Pertama

\begin{tabular}{|c|c|c|}
\hline $\begin{array}{c}\text { Kerja sama } \\
\text { (Cooperate) }\end{array}$ & $\begin{array}{c}\text { Tanggung Jawab } \\
\text { (Responble) }\end{array}$ & $\begin{array}{c}\text { Percaya Diri } \\
\text { (Confidence) }\end{array}$ \\
\hline 23 & 22 & 21 \\
\hline
\end{tabular}

Hasil penelitian terhadap karakter siswa pada minggu pertama dilakukan kegiatan literasi. Observer mengamati perilaku siswa yang terlihat selama kegiatan literasi. Perilaku yang terlihat antara lain: Sebanyak 26 siswa terlihat bekerja sama dan 4 siswa tidak terlihat bekerja sama, sebanyak 25 siswa terlihat bertanggung jawab dan 5 siswa, 24 siswa terlihat percaya diri dan 6 siswa tidak percaya diri.

Tabel 3. Perilaku Pada Minggu Ketiga

\begin{tabular}{|c|c|c|}
\hline $\begin{array}{c}\text { Kerja sama } \\
\text { (Cooperate) }\end{array}$ & $\begin{array}{c}\text { Tanggung Jawab } \\
\text { (Responble) }\end{array}$ & $\begin{array}{c}\text { Percaya Diri } \\
\text { (Confidence) }\end{array}$ \\
\hline 26 & 25 & 24 \\
\hline
\end{tabular}

Berdasarkan kegiatan yang dilakukan mulai perilaku positif siswa dari sebelum kegiatan sampai akhir kegiatan. Perilaku positif siswa terus mengalami kenaikan. Pada hari pertama perilaku positif siswa dari sebelumnya terlihat 20 siswa bekerja sama menjadi 22, sebelumnya terlihat 14 siswa bertanggung jawab menjadi 20 siswa bertanggung jawab, sebelumnya terlihat 17 siswa yang percaya diri menjadi 20 siswa percaya diri.

Pada minggu pertama perilaku positif siswa dari sebelumnya terlihat 22 siswa bekerja sama menjadi 23, sebelumnya terlihat 20 siswa bertanggung jawab menjadi 22 siswa bertanggung jawab, sebelumnya terlihat 20 siswa yang percaya diri menjadi 21 siswa percaya diri.

Pada minggu ketiga terjadi kenaikan yang signifikan. Perilaku positif siswa dari sebelumnya terlihat 23 siswa bekerja sama menjadi 26, sebelumnya terlihat 22 siswa bertanggung jawab menjadi 25 siswa bertanggung jawab, sebelumnya terlihat 21 siswa yang percaya diri menjadi 24 siswa percaya diri. Selama proses kegiatan siswa tidak mendapatkan intervensi untuk melakukan kegiatan selain kegiatan yang di minta oleh panitia. Oleh karena itu, efeknya dapat dikatakan benarbenar original atau tanpa campur tangan orang lain. Peningkatan tersebut dapat kita lihat pada grafik berikut:

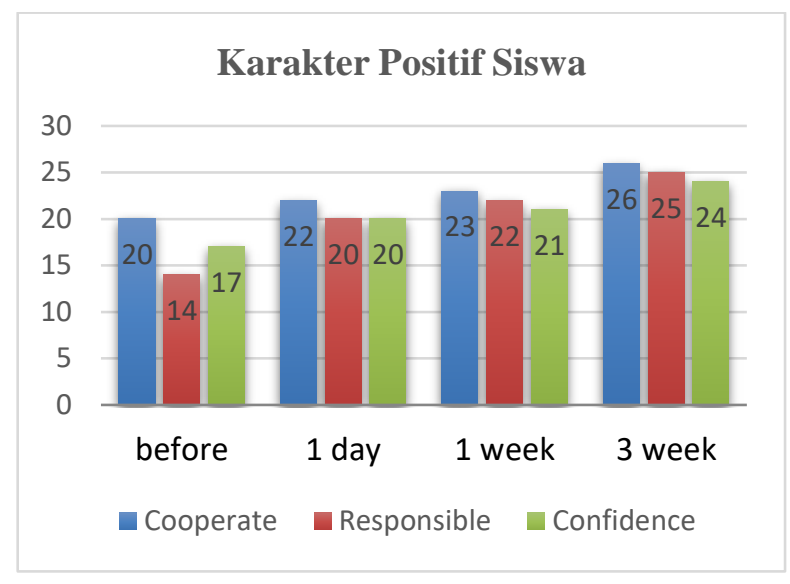

Grafik.1 Peningkatan Karakter Siswa

Berdasarkan pengamatan yang dilakukan oleh peneliti juga terjadi peningkatan terhadap minat baca anak sebelum dan sesudah diterapkannya literasi membaca dengan menggunakan cerita rakyat. Hasil penilitian selama kegiatan literasi membaca menunjukan terjadinya peningkatan pada hari pertama 20 siswa yang tertarik, pada minggu pertama sebanyak 23 siswa yang tertarik, kemudian pada minggu ketiga sebanyak 27 siswa tertarik pada kegiatan membaca. Hasil grafik menunjukan terjadinya peningkatan yang signifikan pada pembentukan membaca dari sebelum dan sesudah diterapkannya literasi membaca dengan cerita rakyat.

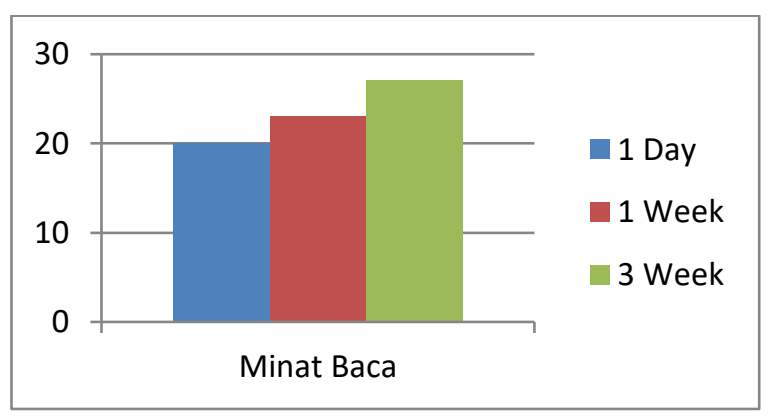

Grafik.2 Peningkatan Minat Membaca Siswa 
1020 Literasi membaca untuk meningkatkan karakter positif siswa sekolah dasar-Nang Suarni, Taufina, Ahmad Zikri

\section{SIMPULAN}

Penelitian ini menguji efek pembentukan karakter positif yang ditimbulkan pada kegiatan literasi membaca dengan menggunakan cerita rakyat. Mengingat keterbatasan bukti ilmiah dalam kegiatan ini, kami menyelidiki secara empiris efek dari literasi membaca ini. Kegiatan pertama menunjukan bahwa dengan menggunakan literasi membaca dengan menggunakan cerita rakyat ini dapat membentuk perilaku positif siswa. Dalam kegiatan literasi membaca ini siswa tidak mendapatkan paksaan dari pihak manapun dan dapat di lihat dari kegiatan rekrut anggota yang dilakukan panitia.

Selain itu selama proses kegiatan orang tua dan anak tidak dibatasi dalam proses komunikasi sehingga tidak mempengaruhi hasil akhir kegiatan. Selain itu, penelitian kami menggunakan dasar pembelajaran yang baik pada sekolah dasar. Peneliti berharap dengan penelitian ini dapat mengembangkan bahan ajar literasi membaca yang baik. Sesuai dengan Proses membaca yang sesungguhnya terdiri atas tiga tahap, yaitu: (1) prabaca, (2) saat baca, dan (3) pascabaca (Somadayo, 2011:35-38).

Dan diharapkan dengan cerita rakyat yang dapat digunakan di lingkungan SD diharapkan siswa dapat lebih memperhatikan teks bacaan dan meningkatkan rasa ingin tahu serta memiliki daya tarik tersendiri bagi siswa terhadap teks bacaan. Sebagaimana menurut Anies Baswedan, hal yang perlu dilakukan yaitu mengajarkan anak membaca, lalu membiasakan anak membaca hingga menjadi karakter, setelah itu barulah menjadi budaya. Jadi, budaya membaca itu hadir karena ada kebiasaan membaca. Kebiasaan membaca ada jika ada rencana membaca secara rutin dan rutinitas dalam membaca.

\section{UCAPAN TERIMAKASIH}

Terima kasih kepada Universitas Negeri Padang yang telah membantu memfasilitasi penelitian yang dilakukan mulai dari pembimbing sampai dengan artikel ini.

\section{DAFTAR PUSTAKA}

Alwasilah, A. Chaedar. 2012. Pokoknya Rekayasa Literasi. Bandung: Kiblat Buku Utama.

Baleiro, Rita. 2011. A Definition of Literary Literacy: A Content Analysis of Literature Syllabuses and Interviews with Portuguese Lecturers of Literature. Journal of New Horizons in Education, (Online), Volume 1, Issue 4 ,

(http://www.tojned.net/pdf/tojnedv01i0 4-02.pdf, diakses tanggal 25 Maret 2016.

Binkley, Marilyn dan Williams, Trevor. 1996. Reading Literacy in the United States: Findings From the IEA Reading Literacy Study. Washington: Government Printing Office.

Borg. W.R. Gall, M.D. 1983. Educational Research: An Instroduction: New York: Longman.

Depdiknas. 2008a. Model Silabus Tematik Kelas I. Jakarta: Direktorat Jenderal Manajemen Pendidikan Dasar dan Menengah.

2008b. Peraturan Menteri Pendidikan Nasional. Jakarta: Direktorat Jenderal Manajemen Pendidikan Dasar dan Menengah.

Gardner, Howard. 2003. Multiple Intelligences; Kecerdasan Majemuk, Teori dalam Praktek. Batam: Interaksara.

Geske, Andrejs dan Ozola, Antra. 2008. Factors Influencing Reading Literacy at The Primary School Level. Journal Problems of Education in The 21st Century, (online) Vol. 6, (http://www.jbse.webinfo.lt/7177.Geske.pdf, diakses 11 April 2016).

Keefe, Elizabeth B. dan Copeland, Susan R. 2011. What Is Literacy? The Power of a Definition. Journal Research \& Practice for Persons with Severe Disabilities, 
1021 Literasi membaca untuk meningkatkan karakter positif siswa sekolah dasar-Nang Suarni, Taufina, Ahmad Zikri

(Online), Vol. 36 No. 3-4, (http://www.pealcenter.org/images/What_i s_Literacy.pdf, diakses 25 Maret 2016).

Kemendiknas. 2010. Pembelajaran Aktif di Perguruan Tinggi. Jakarta: Kemendiknas.

2011a. Standar Nasional Pendidikan. Jakarta: Kemendiknas.

Miles, Matthew B. \& Huberman, A. Michael. 1994. Qualitative Data Analysis. London New Delhi: Sage Publications.

Ngaka, Willy dan Masaazi, Fred Masagazi. 2015. Participatory Literacy Learning in an African Context: Perspectives from the Ombaderuku Primary School in the Arua District, Uganda. Journal of Language \& Literacy Education, (Online), Vol. $11 \quad$ No. 1, (http://jolle.coe.uga.edu/wpcontent/uploads/2015/04/NgakaMasaaz i_Final-.pdf, diakses 13 Februari 2016).

Nieto, Sonia. 2013. Language, Literacy, and Culture: Aha! Moments in Personal and Sociopolitical Understanding. Journal of Language \& Literacy Education, (Online), Vol. 9 No. 1, (http://files.eric.ed.gov/fulltext/EJ1008 170.pdf, diakses 13 Februari 2016).

Taufina 2010. Pelaksanaan Pembelajaran Tematik di Kelas Rendah. Laporan Penelitian Pascasarjana UNP. Tahun Anggaran 2010.

2011a. Penerapan Pembelajaran Tematik untuk Meningkatkan Aktivitas dan Hasil Belajar di Kelas Rendah SD - Laporan Penelitian Pascasarjana UNP. Tahun Anggaran 2011.

2011b. Mozaik Pembelajaran Inovatif. Padang: Sukabina Press.

2012. Peningkatan Aktivitas dan Proses Pembelajaran Tematik dengan Menggunakan Pembelajaran di Kelas Rendah SD. Laporan Penelitian Pascasarjana UNP. Tahun Anggaran 2012.

2014a. Implementasi Pembelajaran Tematik Terpadu Kurikulum 2013.
Laporan Penelitian LPMP Tahun anggaran 2014.

2014b. Pengembangan Pembelajaran Tematik Terpadu dengan Menggunakan Multiple Intellegence di Kelas I SD. Laporan Penelitian DP2M Tahun Anggaran 2014.

Triplett, Cheri Foster. 2002. Dialogic Responsiveness: Toward Synthesis, Complexity, and Holism in Our Reponses to Young Literacy Learners. Journal of Literacy Research, (Online), Vol. 34 No. 1 , (http://jlr.sagepub.com/content/34/1/11 9.full.pdf+html, diakses 13 Februari 2016) 